\title{
Application of Webster's Method to Optimizing Traffic Lights at the Intersection of Bantul - Nasional III Street, Yogyakarta
}

\author{
Prihantini $^{1, *}$, Albert Hosea Santoso ${ }^{2, * *}$, Hanifa Reygina Fajrin ${ }^{2, * * *}$ \\ ${ }^{1}$ Department of Mathematics Education, Faculty of Mathematics and Science, Yogyakarta State University \\ ${ }^{2}$ Department of Mathematics, Faculty of Mathematics and Science, Gadjah Mada University \\ Email: titinprihantini4@gmail.com*, albert.h.s.@mail.ugm.ac.id**, hanifareygina@mail.ugm.ac.id***
}

\begin{abstract}
Indonesia is a developing country with the fourth largest population in the world. Population in one of the provinces in Indonesia, namely Yogyakarta Special Region. Based on data from the Badan Pusat Statistik (BPS), the Special Region of Yogyakarta reached 3.8 million people in 2018. Of this number, almost one third (1.2 million people) are residents of Sleman. While the region with the next largest population is Bantul with 1 million inhabitants. Increasing population causes the need to move and other needs, as well as activities in the education, office and trade sectors also increase. This increase will also affect transportation by increasing the number of vehicles, but this increase is not in line with the existing traffic light updates. As a result, the capacity of the street section has decreased and caused congestion, for example at the APILL intersection on Bantul-Nasional III Street, Yogyakarta. This shows that the existing traffic light settings are not optimal. Therefore, it is necessary to evaluate the duration of the traffic lights to minimize congestion. This research was conducted to analyze the traffic light system at the APILL intersection on Bantul-Nasional III Street, Yogyakarta using the Webster method. The results of calculations using this method obtained results for the Bantul Street (north), the duration of the green light 30 seconds, yellow 3 seconds and red 28 seconds. For Nasional III Street (East), the duration of the green light is 24 seconds, yellow is 3 seconds and red is 34 seconds. For Bantul Street (south), the duration of the green light is 30 seconds, yellow is 3 seconds and red is 28 seconds. For Nasional III Street (West), the duration of the green light is 24 seconds, yellow is 3 seconds and red is 34 seconds. These results look more optimal than those on the field today.
\end{abstract}

Keywords: Traffic Performance, Webster Methode, Traffic Lights, Traffic Congestion, Optimization

\section{INTRODUCTION}

Transportation in general and traffic in particular is a phenomenon that is seen everyday in human life. The higher the level of movement of citizens of a city, the higher the level of travel. If this increase in travel is not followed by an increase in adequate transportation infrastructure, there will be an imbalance between demand and supply which will eventually lead to an unevenness in mobility in the form of congestion. Traffic congestion in a city or a place now is no longer a strange thing that can occur in a segment or cross streets, congestion arises because of conflicting movements that come in each direction of the intersection and to reduce this conflict many controls are carried out to optimize the intersection with use traffic lights.

Traffic is a condition with a regulation using traffic lights installed at an intersection in order to regulate the flow of traffic. The regulation of traffic flow at an intersection is basically intended for how the movement of vehicles in each group of vehicle movements can move alternately so that they do not interfere with each other. There are various types of controls using traffic lights where this consideration is very dependent on the situation and intersection conditions such as volume, intersection geometry, and so on.

Adaptive and synchronous traffic control systems have been used in many developed countries. With the adaptive traffic control system, the duration of red and green is adjusted to the density of vehicle arrivals. With this system, it is expected that the duration of vehicle waiting times from all directions tends to be the same and will not exceed one cycle. In other words there are no vehicles that experience red cues twice. There is a synchronous traffic control system to reduce the travel time of the main Street. Arrangements are synchronized with each other so that most of the vehicles on the main Street don't wait too long for green cues.

Synchronous traffic control is used to reduce the duration of vehicles waiting on the main street. The synchronization process in synchronous traffic settings is quite complicated. Determination of the time and duration of the green involves many parameters, such as: the green time the main direction of the next traffic control, the speed and acceleration of the vehicle, as well as the vehicle travel time from one traffic setting to another traffic setting. Calculation of green time must also be supported by sensors of the presence of vehicles on the main Street which is quite a lot. To keep in sync, a synchronous traffic regulator cannot be adaptive.

An increase in the density of vehicle arrivals from a direction can increase the duration of a vehicle's waiting time in that direction to get a green light signal. In this study, the authors make the concept of adaptive synchronous traffic control systems. The system is not synchronized with other traffic regulators, but with the 
collapse of the vehicle arrival density data from the main direction. With this system, although there are changes in the density of vehicle arrivals from several directions, it is expected that the duration of the vehicle waiting time can be made at a minimum, especially for the main directions. This research is expected to be a solution to minimize traffic congestion.

\section{MATERIALS AND METHODS}

\section{Traffic Light Characteristics.}

Traffic lights are auxiliary devices with lights mounted on function with lights mounted on the lane for the purpose of installing a traffic flow. Traffic flow settings at the time of movement of traffic for the movement of vehicles in each group movement can be alternately unrelated. There are various kinds of arrangements using traffic lights where this consideration is very dependent on the discussion and adjustment of existing conditions such as volume, geometry, intersections and so forth. Geometry and traffic conditions will affect the capacity and performance of traffic on the planning. Therefore, planning must be able to decide according to the needs of each group according to needs.

The traffic light system uses the following types of lights:

a. Green lights (green); is a vehicle that gets the signal must move forward.

b. Yellow lights (yellow); is a vehicle that receives compensation to make a decision to apply the next traffic lights (green or red lights).

c. Red light (red); is a vehicle that gets to stop before the stop line.

Please note that with the new traffic light regulations for vehicles that turn left as long as they are not set, the vehicles that are allowed to turn the road continue. Repaired with various lights this applies to set the traffic lights on time.

\section{Traffic conditions and movements}

Obtained four forms, basic traffic is traffic at the time of traffic

a. Dive

Diverging is the event separating a vehicle from one current to another lane.

b. Merge

The event of the joining of vehicles moving on several compilation roads joins at one point of storage, and is also present when the vehicle makes a shopping and joining movement.

c. Weave

Weaving is a meeting of two or more traffic flows that run in the same direction along a path on a highway without the help of traffic signs.

\section{d. Crossing}

Crossing events between vehicle flows from one lane to an intersection usually depend on such conditions which will lead to conflicts on road changes.

\section{Webster's method}

Webster's method is a method used to determine the time of a traffic light that has been developed by F.V. Webster. To determine the time to turn on the traffic lights can be done the following steps.

\section{A. Determine the saturation current}

Table 1. Saturation current at junction (Webster method)

\begin{tabular}{ll}
\hline Street Width $(\mathbf{m})$ & Street Length $(\mathbf{s m p} / \mathbf{j})$ \\
\hline 3.05 & 1850 \\
3.35 & 1875 \\
3.65 & 1900 \\
3.95 & 1950 \\
4.25 & 2075 \\
4.60 & 2250 \\
4.90 & 2475 \\
5.20 & 2700 \\
\hline Source, Diktat Lecture 9 RLL, ITP teaching staff
\end{tabular}

If the width (l) exceeds this, then the saturation current $=1 \times 525(\mathrm{smp} / \mathrm{h})$

Specifically for good intersections (free vision, etc.) the number is added by $20 \%$, and for bad intersections (inclines, insufficient views, etc.) these figures should be reduced by $15 \%$.

The ratio of normal current to saturated current $(\mathrm{y})$, is $=\mathrm{Q} / \mathrm{S}$

The measure of congestion is expressed as Ratio Phase, $F R=F R$ ymax

Where: $\mathrm{S}=$ saturated current $(\mathrm{smp} / \mathrm{h})$

$\mathrm{Q}=$ real current $(\mathrm{smp} / \mathrm{h})$

\section{B. Determine the optimum cycle time}

The factor needed to calculate the maximum cycle time (the optimum cycle time setting) is the lost time (L), which is the length of time for a full cycle when there is no vehicle. This is done not only all red lights time and red lights time / red / yellow but also as the preparation time of the road (starting-up) and preparation for the stop (tailing-off) that occurs when the color change of the lamp. Wasted time is calculated by the formula:

$\mathrm{Lt}=2 \mathrm{n}+\mathrm{R}$

$\mathrm{n} \quad=$ Number of phases

$\mathrm{R}=$ Time of all red and red lights time $/ \mathrm{red} /$ yellow $(2$ $+3=5$ second)

Lt $=$ Can also be defined as the number of periods of green lights time reduced by one second per green.

By road research laboratories in the UK, providing optimum cycle time $(\mathrm{Co})$ is 
$\mathrm{Co}=\frac{1,5 \cdot \mathrm{Lt}+5}{1-\mathrm{FR}}$

Allowable lost time for the value of $y$ in each direction:

$\frac{\text { FR1 }}{\text { FR2 }}=\frac{1+\mathrm{q} 1}{1+\mathrm{q} 2}$ sehingga $\quad \mathrm{g}_{1}=\frac{\mathrm{y} 1+(\mathrm{Co}-\mathrm{Lt})}{\mathrm{FR}}-1$ second

Description:

$$
\mathrm{g}_{2}=\frac{\mathrm{y} 2+(\mathrm{Co}-\mathrm{Lt})}{\mathrm{FR}}-1 \text { second }
$$

$\mathrm{FR}=$ Phase Ratio

$\mathrm{q}=$ Vehicle flow (vehicle/hours)

$\mathrm{g} \quad=$ Green lights time period (second)

Table 2. Cycle length limit table

\begin{tabular}{ll}
\hline Number of Phase & Recommended cycle lenght \\
\hline 2 & $40-80$ second \\
3 & $50-100$ second \\
4 & $80-130$ second \\
\hline
\end{tabular}

Actual green lights time

$g a=g+k-L t$

Where:

$g a=$ Green lights time aktual (second)

$g=$ Green lights time siklus (second)

$k=$ Yellow lights time

$L t=$ lost time

Nasional III Street (West) and Nasional III Street (East). Geometric description of the four-way intersection can be seen in the image below.

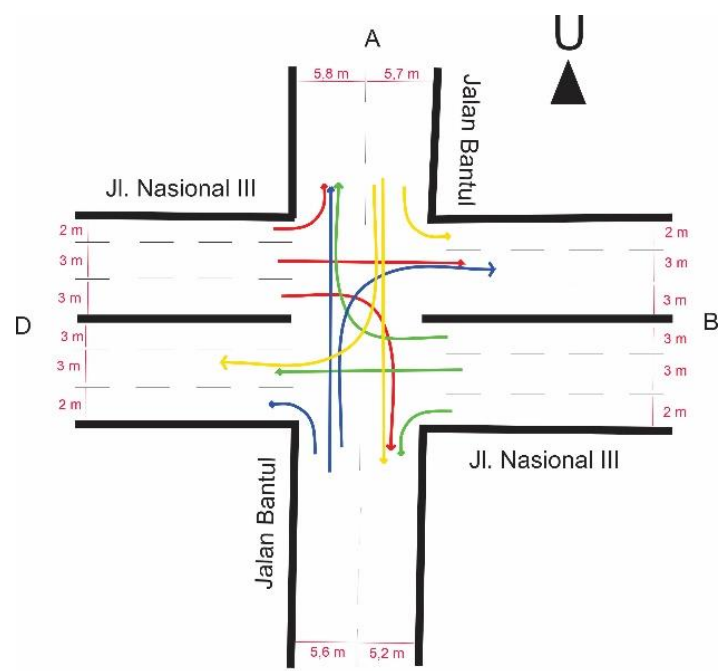

Figure 1. Street Junction.

C

In Figure 1, it has the following information:

1) The north section (coded: A) is Bantul Street which has 2 lanes, with an entrance width of $5.8 \mathrm{~m}$ and an exit lane of $5.7 \mathrm{~m}$

2) The east part (coded: B) is Nasional III Street which has 2 lanes with $8 \mathrm{~m}$ wide entrance and exit lanes.
3) The southern part (coded: C) is Bantul Street has 2 lanes with an entrance width of $5.2 \mathrm{~m}$ and an exit of $5.6 \mathrm{~m}$

4) The west part (coded: D) is National III Street which has 2 lanes with a width of $8 \mathrm{~m}$ in and out lanes.

The old traffic light cycle data at intersection four Bantul-Nasional III Street, Yogyakarta.

Table 3. Long cycle of traffic lights

\begin{tabular}{lccc}
\hline Street Width (m) & $\begin{array}{c}\text { Red } \\
\text { (second) }\end{array}$ & $\begin{array}{c}\text { Yellow } \\
\text { (second) }\end{array}$ & $\begin{array}{c}\text { Green } \\
\text { (second) }\end{array}$ \\
\hline Bantul (North) & 106 & 3 & 32 \\
Nasional III (East) & 103 & 3 & 28 \\
Bantul (South) & 106 & 3 & 32 \\
Nasional III Street & 103 & 3 & 28 \\
(West) & & & \\
\hline
\end{tabular}

Traffic volume data is obtained by citing the research we found. In that study, researchers conducted a survey and recorded all types of vehicles that crossed the intersection. Hourly traffic volume at 15-minute intervals, which are then converted from hourly vehicles to per-hour passenger car units.

Retrieval of traffic flow data is carried out for one day, namely Wednesday, March 15, 2017 at 06: 00-18: 30 which can be seen in the following table.

Table 4. Data of vehicles per times.

\begin{tabular}{|c|c|c|c|}
\hline \multirow{2}{*}{ Interval } & \multirow{2}{*}{$\begin{array}{l}\text { Total } \\
\text { vehicles/times }\end{array}$} & \multirow{2}{*}{ Interval } & \multirow{2}{*}{$\begin{array}{l}\text { Total } \\
\text { vehicles/times }\end{array}$} \\
\hline & & & \\
\hline $06.00-07.00$ & 8957 & $12.00-13.00$ & 7447 \\
\hline $06.15-07.15$ & 10848 & $12.15-13.15$ & 7629 \\
\hline $06.30-07.30$ & 12165 & $12.30-13.30$ & 7707 \\
\hline $06.45-07.45$ & 12734 & $12.45-13.45$ & 7822 \\
\hline $07.00-08.00$ & 12831 & $13.00-14.00$ & 8174 \\
\hline $07.15-08.15$ & 12498 & $13.15-14.15$ & 8433 \\
\hline $07.30-08.30$ & 11778 & $13.30-14.30$ & 8912 \\
\hline $07.45-08.45$ & 10848 & $13.45-14.45$ & 9009 \\
\hline $08.00-09.00$ & 9834 & $14.00-15.00$ & 9204 \\
\hline $08.15-09.15$ & 9144 & $14.15-15.15$ & 9437 \\
\hline $08.30-09.30$ & 9010 & $14.30-15.30$ & 9570 \\
\hline $08.45-09.45$ & 8545 & $14.45-15.45$ & 9812 \\
\hline $09.00-10.00$ & 8113 & $15.00-16.00$ & 9781 \\
\hline $09.15-10.15$ & 8178 & $15.15-16.15$ & 9730 \\
\hline $09.30-10.30$ & 7819 & $15.30-16.30$ & 9831 \\
\hline $09.45-10.45$ & 8148 & $15.45-16.45$ & 10061 \\
\hline $10.00-11.00$ & 8259 & $16.00-17.00$ & 10277 \\
\hline $10.15-11.15$ & 8058 & $16.15-17.15$ & 10423 \\
\hline $10.30-11.30$ & 7995 & $16.30-17.30$ & 10542 \\
\hline $10.45-11.45$ & 7889 & $16.45-17.45$ & 10571 \\
\hline $11.00-12.00$ & 7689 & $17.00-18.00$ & 10561 \\
\hline $11.15-12.15$ & 7597 & $17.15-18.15$ & 7966 \\
\hline $11.30-12.30$ & 7467 & $17.30-18.30$ & 5273 \\
\hline $11.45-12.45$ & 7545 & & \\
\hline
\end{tabular}


Based on the data above, it can be seen that the Peak Hour Volume is at 07: 00-08: 00 with details that can be seen in the following table:

Table 5. Peak Hour Volume

\begin{tabular}{rrcccc}
\hline INTERVAL & STREET & HV & LV & MC & UM \\
\hline & A to B (LEFT) & 7 & 40 & 260 & 2 \\
A to C (STRAIGHT) & 9 & 124 & 912 & 20 \\
A to D (RIGHT) & 0 & 67 & 617 & 3 \\
Total & 16 & 231 & 1789 & 25 \\
07.00-08.00 & B to C (LEFT) & 1 & 32 & 875 & 22 \\
\cline { 2 - 6 } & B to D (STRAIGHT) & 94 & 505 & 1938 & 6 \\
& B to A (RIGHT) & 11 & 66 & 423 & 1 \\
Total & 106 & 603 & 3236 & 29 \\
& C to D (LEFT) & 2 & 61 & 340 & 10 \\
& C to A (STRAIGHT) & 15 & 196 & 2800 & 30 \\
C to B (RIGHT) & 11 & 109 & 973 & 9 \\
& Total & 28 & 366 & 4113 & 49 \\
& D to A (LEFT) & 1 & 26 & 19 & 1 \\
& D to B (STRAIGHT) & 61 & 274 & 1141 & 4 \\
D to C (RIGHT) & 10 & 55 & 637 & 11 \\
Total & 72 & 355 & 1797 & 16 \\
\hline
\end{tabular}

Table 5. Traffic Volume of APILL intersection.

\begin{tabular}{|c|c|c|c|c|c|c|c|c|}
\hline \multirow[b]{3}{*}{$\begin{array}{c}\text { Street } \\
\text { Segment } \\
\text { Code }\end{array}$} & \multicolumn{2}{|c|}{$\mathbf{L V}$} & \multicolumn{2}{|c|}{ HV } & \multicolumn{2}{|c|}{ MC } & & \\
\hline & \multicolumn{2}{|c|}{$\operatorname{Emp}=1,0$} & \multicolumn{2}{|c|}{$E m p=1,3$} & \multicolumn{2}{|c|}{$\operatorname{Emp}=0,2$} & & \\
\hline & 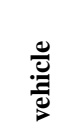 & है & $\frac{0}{2}$ & है & $\frac{\frac{0}{e}}{\stackrel{0}{\frac{0}{2}}}$ & 을 & $\begin{array}{c}\text { vehicles } \\
\text { / times }\end{array}$ & $\begin{array}{c}\text { Smp } \\
/ \\
\text { times }\end{array}$ \\
\hline A & 231 & 231 & 16 & 20 & 1789 & 357 & 2036 & 608 \\
\hline B & 603 & 603 & 106 & 137 & 3236 & 647 & 3945 & 1387 \\
\hline $\mathrm{C}$ & 366 & 366 & 28 & 36 & 4113 & 822 & 4507 & 1224 \\
\hline D & 355 & 355 & 72 & 93 & 1797 & 359 & 2224 & 807 \\
\hline
\end{tabular}

Description:
$(\mathrm{LV})=$ Light Vehicle
$(\mathrm{HV})=$ Heavy Vehicle
$(\mathrm{MC})=$ Motorcycle
$(\mathrm{UM})=$ Unmotorycle or non-motorized vehicles

Next, the optimum cycle time will be determined (Co)

$$
\mathrm{Co}=\frac{1,5 \cdot \mathrm{Lt}+5}{1-\mathrm{FR}}
$$

a. Yellow lights time $(\mathrm{R})=3$ second

b. Saturated current at each intersection
For north direction
$=5,7 \times 525=2992,5$
For east direction
$=8 \times 525=4200$
For south direction
$=5,6 \times 525=2940$
For west direction
$=8 \times 525=4200$

c. Determine the value of $y$

$$
\begin{aligned}
& y u=\frac{608}{2992,5}=0,203 \\
& y \mathrm{t}=\frac{1387}{4200}=0,33 \\
& y \mathrm{~s}=\frac{1224}{2940}=0,416 \\
& y \mathrm{~b}=\frac{807}{4200}=0,192 \\
& =\sum y_{\max } \\
& =0,416+0,33 \\
& =0,746
\end{aligned}
$$

$\mathrm{FR}=\sum y_{\max }$

d. d. Determine lost time ( $\mathrm{Lt})$

$$
\begin{aligned}
\mathrm{Lt} & =2 \mathrm{n}+\mathrm{R} \\
& =2(2)+3 \\
& =7
\end{aligned}
$$

So the optimum cycle time is:

$$
\begin{aligned}
& C o=\frac{1,5 . \mathrm{Lt}+5}{1-\mathrm{FR}} \\
& \mathrm{Co}=\frac{1,5 \times 7+5}{1-0,746} \\
& \mathrm{Co}=\frac{15,5}{0,254} \\
& \mathrm{Co}=61 \text { second }
\end{aligned}
$$

Total cycle time of the maximum Green lights

$$
\begin{aligned}
& =C 0-L t \\
& =61-7 \\
& =54 \text { second }
\end{aligned}
$$

Green lights time

$$
\begin{aligned}
\text { Phase I } & =\frac{0,416 \times 54}{0,746} \\
& =\frac{22.464}{0,746} \\
& =30 \text { second }
\end{aligned}
$$

Phase II $=\frac{0,33 \times 54}{0,746}$

$$
\begin{aligned}
& =\frac{18}{0,746} \\
& =24 \text { second }
\end{aligned}
$$

Red lights time

Phase I $=C 0-$ Green lights time-Yellow lights time

$$
=61-30-3
$$$$
=28 \text { second }
$$

Phase II $=C 0-$ Green lights time - Yellow lights time

$$
\begin{aligned}
& =61-24-3 \\
& =34 \text { second }
\end{aligned}
$$


Table 6. Cycle time of traffic lights.

\begin{tabular}{llll}
\hline Direction & Green & Yellow & Red \\
\hline North & 30 & 3 & 28 \\
East & 24 & 3 & 34 \\
South & 30 & 3 & 28 \\
West & 24 & 3 & 34 \\
\hline
\end{tabular}

Based on the results previously described, a discussion was made about the application of the Webster Method in traffic lights at four intersections of Bantul (north), Bantul (south), National III (West) and National III (East) Streets. The discussion included the intersection geometry data, vehicle volume, optimum cycle time, green time and red time.

The geometry of the intersection of the four Streets of Bantul (north), Bantul Street (south), Nasional III Street (West) and Nasional III Street (East) has a median of streets, where the inflow and outflow are not in the same lane. Based on Table 4.1, the traffic cycle data at APILL intersection on Bantul - Nasional III Street Yogyakarta uses 2 phases, where for Bantul Street (south) and Bantul Street (north) the duration of red is 106 seconds, yellow is 3 seconds and green is equal to 32 seconds. For Nasional III Street (East) and Nasional III Street (West) the duration of red is 103 seconds, yellow is 3 seconds and green is 28 seconds

The APILL intersection on Bantul-Nasional III Street Yogyakarta is an intersection that often occurs in traffic, this is caused by the high volume of vehicles. The peak traffic volume of 12.5 hours of observation is obtained at 07.00-08.00 WIB. The peak traffic volume on the Bantul Street (north) with the number of light vehicles is 231 vehicles / hour, heavy vehicles is 16 vehicles / hour and motorbikes is 1789 vehicles / hour, all types of vehicles are converted to passenger car units (junior high school), so $231 \mathrm{pcu} /$ hour for light vehicles, $20 \mathrm{pcu} /$ hour for heavy vehicles and 357 for motorbikes, so that peak hour volume of $608 \mathrm{pcu} / \mathrm{hour}$ is obtained.

The volume of peak traffic on Nasional III Street (East) with the number of light vehicles is 603 vehicles / hour, heavy vehicles is 106 vehicles/hour and motorbikes is 3236 vehicles/hour, all types of vehicles are converted into passenger car units (junior high school), so that $603 \mathrm{smp} /$ hour is obtained for light vehicles, $137 \mathrm{pcu} / \mathrm{hour}$ for heavy vehicles and 647 for motorbikes, so that peak hour volume is $1387 \mathrm{pcu} /$ hour.

The peak traffic volume on the Bantul Street (south) with the number of light vehicles is 366 vehicles / hour, heavy vehicles is 28 vehicles/hour and motorbikes are 4113 vehicles/hour, all types of vehicles are converted to passenger car units (junior high school), so $366 \mathrm{pcu} /$ hour for light vehicles, $36 \mathrm{pcu} /$ hour for heavy vehicles and 822 for motorbikes, so that peak hour volume is $1224 \mathrm{pcu} /$ hour.

The peak traffic volume on Nasional III Street (West) with the number of light vehicles is 355 vehicles / hour, heavy vehicles is 72 vehicles / hour and motorbikes is 1797 vehicles / hour, all types of vehicles are converted into passenger car units (junior high school), so that 355 pcu / hour is obtained for light vehicles, $93 \mathrm{pcu} /$ hour for heavy vehicles and 359 for motorbikes, so a peak hour volume of $807 \mathrm{pcu} /$ hour is obtained.

The optimum cycle time at the intersection of four is 61 seconds, this looks more optimal, compared to the optimum cycle time in the field of 133 seconds.

The maximum number of green time cycles is obtained by subtracting the optimal cycle time from the lost time (Lt), so that the maximum number of green time cycles is 54 seconds.

The green time for each phase is obtained by multiplying phase each phase by the maximum number of time cycles, divided by the phase ratio, so that the green time for the Bantul (north) Street is 30 while the green time in the field is 32 seconds. The green time for Nasional III Street (East) is 24 seconds, while the green time in the field is 28 seconds. The green time for the Bantul (south) Street is 30 seconds, while the green time on the field is 32 seconds and the green time for Nasional III Street (West) is 24 seconds, while the green time on the field is 28 seconds. This looks more efficient than the green time on the ground.

The red time for each phase is obtained by subtracting the optimum cycle time between green time and yellow time, so that it is obtained

The red time for the Bantul Street (north) is 28 while the red time in the field is 106 seconds. The red time for Nasional III Street (East) is 34 seconds, while the red time on the field is 103 seconds. The red time for Bantul (south) Street is 28 seconds, while the red time in the field is 106 seconds and the red time for Nasional III Street (West) is 34 seconds, while the red time in the field is 103 seconds. This looks more efficient than the red time on the ground.

\section{RESULTS AND DISCUSSION}

The conclusion that can be drawn based on the research objectives is how to adjust the duration of the traffic lights using the Webster method obtained results for the Bantul Street (north), the duration of the green light 30 seconds, yellow 3 seconds and red 28 seconds. For Nasional III Street (East), the duration of the green light 24 second, yellow 3 second and red 34 second. For Bantul Street (south), ), the duration of the green light 30 second, yellow 3 second and red 28 second. For Nasional III Street (West), ), the duration of the green light 24 second, yellow 3 second and red 34 second.

\section{CONCLUSION}

The results of calculations using this method obtained results for the Bantul Street (north), the duration of the 
green light 30 seconds, yellow 3 seconds and red 28 seconds. For Nasional III Street (East), the duration of the green light is 24 seconds, yellow is 3 seconds and red is 34 seconds. For Bantul Street (south), the duration of the green light is 30 seconds, yellow is 3 seconds and red is 28 seconds. For Nasional III Street (West), the duration of the green light is 24 seconds, yellow is 3 seconds and red is 34 seconds. These results look more optimal than those on the field today. The suggestion in this study is for the next researcher to use a compatible graph at the intersection of Bantul - Nasional III Street Yogyakarta, by adding the assumptions and variables used.

\section{ACKNOWLEDGEMENTS}

We thank our colleagues from Gadjah Mada University and Yogyakarta State University for providing insights and expertise that greatly assisted this research.our completion of this project could not have been accomplished without the support of each other.

\section{REFERENCES}

Badan Pusat Statistik. 2010. Penduduk Indonesia Menurut Provinsi dan Kab/Kota SP 2010. BPS, Badan Pusat Statistik, Jakarta

Fitria, Binti Tsamrotul. 2015. Penurunan Model Traffic Flow Berdasarkan Hukum - Hukum Kesetimbangan. [Dissertation]. Maulana Malik Ibrahim Islamic State University, Malang [Indonesian]

Miftahurrahmah. 2016. Aplikasi Teori Graf dalam Pengaturan Lampu Lalu Lintas. [Dissertation]. Alauddin Makassar Islamic State University, Makassar [Indonesian]

Pambudi, Adi Widya. 2017. Kinerja Simpang Bersinyal Jalan Bantul, Ringroad Selatan, Yogyakarta. [Dissertation]. Muhammadiyah Yogyakarta University, Yogyakarta [Indonesian] 